\title{
Knowledge, attitudes and habits regarding oral health among nurses of Clinical hospital center Rijeka
}

\section{Znanja, navike i stavovi medicinskih sestara / tehničara Kliničkog bolničkog centra Rijeka o oralnom zdravlju}

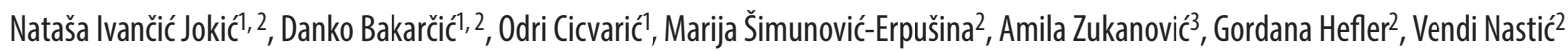 \\ ${ }^{1}$ Katedra za dječju stomatologiju, Fakultet dentalne medicine Sveučilišta u Rijeci, Krešimirova 40, 51000 Rijeka, Republika Hrvatska \\ ${ }^{2}$ Klinika za dentalnu medicinu, Klinički bolnički centar Rijeka, Krešimirova 40, 51000 Rijeka, Republika Hrvatska \\ ${ }^{3}$ Stomatološki fakultet Univerziteta u Sarajevu, Bolnička 4, Sarajevo 71 000, Bosna i Hercegovina
}

\begin{abstract}
Background/Aim: The aim of this study was to investigate oral health knowledge, attitudes and habits regarding oral health among nurses and to evaluate if there is a difference in self-reported oral health behavior in relation to the degree of professional education.
\end{abstract}

Methods: The study was conducted on a sample of 100 subjects, both gender, aged 22 to 62 . The respondents were nurses with completed secondary school (49\%) and nurses with bachelor's or master's degrees in nursing (51\%). The study was conducted via the Croatian version of the Hiroshima University-Dental Behavioral Inventory (HU-DBI) questionnaire.

Results: Nurses with a bachelor's or master's degree had a significantly higher HU-DBI score than nurses with completed secondary school $(p=0.033)$. Statistically significant difference was found in the following questions: I brush each of my teeth carefully $(p=0.026)$, I put off going to the dentist until I have a toothache $(p=0.008)$ and I have had my dentist tell me that I brush very well $(p=0.016)$.

Conclusion: The obtained results show that healthcare professionals with higher education (bachelor's or master's degree in nursing) have more knowledge on oral health and that they apply this knowledge in their daily oral hygiene routine.

Keywords: Attitude of health professionals, nurses, oral health

Running head: Nurses' knowledge on oral health

\section{Sažetak}

Uvod/cilj: Cilj je ovog istraživanja ispitati stupanj znanja i stavove 0 oralnom zdravlju medicinskih sestara, prvostupnica/prvostupnika i magistri/magistara sestrinstva, zaposlenih u KBC-u Rijeka, te vidjeti postoje li razlike u znanju i stavovima u odnosu na stupanj stručne spreme.

Ispitanici i metode: Istraživanje je provedeno na uzorku od 100 ispitanika muškog i ženskog spola, u dobi od 22 do 62 godine. Ispitanici su medicinske sestre sa završenom srednjom školom (49 \%) i prvostupnici ili magistri sestrinstva (51 \%). Istraživanje je provedeno putem upitnika Hiroshima University-Dental Behavioral Inventory (HU-DBI).

Rezultati: Medicinske sestre / medicinski tehničari koji su prvostupnici ili magistri sestrinstva imaju statistički značajno viši ukupan HU-DBI $(p=0,033)$. Statistički značajne razlike nađene su u pitanjima o pažljivom četkanju svakog zuba $(p=0,026), 0$ odgađanju odlaska stomatologu sve dok ne zaboli zub $(p=0,008)$ i 0 tome da im se dogodilo da im stomatolog kaže da dobro četkaju svoje zube $(p=0,016)$.

Zaključak: Dobiveni rezultati pokazuju da medicinske sestre sa završenim studijem sestrinstva imaju više znanja o oralnom zdravlju i da ta znanja primjenjuju u svom svakodnevnom održavanju oralne higijene.

Ključne riječi: medicinske sestre, oralno zdravlje, stavovi zdravstvenih djelatnika

Kratak naslov: Znanje medicinskih sestara / tehničara o oralnom zdravlju

Autor za korespondenciju/Corresponding author: Odri Cicvarić, Katedra za dječju stomatologiju, Fakultet dentalne medicine Sveučilišta u Rijeci, Krešimirova 40, 51000 Rijeka, Republika Hrvatska, e-mail: odri.cicvaric@fdmri.uniri.hr; Tel: +385989202542

\section{Introduction}

Oral health is an essential part of general health. Oral health includes a healthy oral cavity with all its structures: teeth and supporting tissue, oral mucosa, and salivary glands [1, 2]. The key to protecting oral health are good daily oral hygiene habits. Good oral hygiene (brushing, flossing, using mouthwash, etc.) removes an aggregation of microorganisms accumulated on oral surfaces, called oral biofilm. These microorganisms in biofilm cause oral diseases like dental caries, gingival, and periodontal disease [2].
Providing oral health care for hospitalized patients is becoming a standard. Inpatients' good oral health has an impact on their nutritional intake; poor nutritional intake affects the outcome, slows the recovery and thus prolongs the hospital stay. Good oral health also improves inpatients' general health, dignity, and wellbeing [3].

Nurses' awareness of the importance of good oral health care is very important in maintaining good hospital care. 
They should be educated on basic preventive dentistry including the most common oral diseases and their prevention, techniques for identifying and removing plaque, usage of fluorides $[4,5]$.

This study aimed to evaluate knowledge, attitudes, and habits regarding oral health among nurses who are working in the Clinical Hospital Center Rijeka in Rijeka, Croatia. Furthermore, aim was to compare their oral behavior and determine if there is a significant difference between nurses with completed secondary school (SSN) and nurses with bachelor's (BSN) or master's (MSN) degree. It is expected that participants with a higher level of education have higher knowledge and better oral health habits and attitudes.

\section{Methods}

This cross-sectional study was done in 2017 and included 100 participants aged between 22 and 62 .

Nurses that are working in the Clinical Hospital Center Rijeka were included. Those nurses who are working in the Clinic for Dental Medicine of the Clinical Hospital Center Rijeka were excluded from the sample.

Each participant filled in the Hiroshima University-Dental Behavioral Inventory (HU-DBI). Also, information on socioeconomic status (SES) was summoned from each respondent.

Kawamura developed the Hiroshima University-Dental Behavioral Inventory (HU-DBI) for evaluating knowledge, attitudes, and habits regarding oral health. This questionnaire has good reliability (in the adult population, the population of dental students, and in intercultural studies). It is translated into Croatian and validated. HU-DBI consists of 20 questions with a dichotomous response scale (agree or disagree). The total HU-DBI score is calculated by summing up certain answers (agree/disagree). Higher scores mean higher knowledge and better attitudes and habits $[2,4,6$, 7].

Information on SES included: age, gender, marital status (married, not married, divorced), number of children in the family, educational level (secondary school, bachelor's degree, master's degree), work experience (in ages), place of work (which clinic in Clinical Hospital Center Rijeka). Also, information if they are tobacco users (yes/no).

The study was approved by the Ethics committee of the Clinical Hospital Center Rijeka and the Ethics committee of Faculty of Health Studies, and the approval of the Chief Executive Officer and the Director of Nursing.

Informed consent was conducted from each participant.

\section{Data analysis}

Data analysis was done using SPSS 10.0 (SPSS, Chicago, USA). Comparing the difference in answers on each question between nurses with different levels of education was done with the Chi-square test. Mann-Whitney test was used to compare the total HU-DBI score between the two groups. The value $p<0.05$ was taken as the level of significance.

\section{Results}

Of 100 participants, 82 were female and 18 men. The mean age of participants is 45.97 (SD=9.92, min. 22, max. 62). Among all participants, $49 \%$ of them finished secondary school for nurses $(\mathrm{N}=49)$, and $51 \%$ of them have bachelor's or master's degree $(\mathrm{N}=51)$. Mean work experience is 26.9 years for male employees, and 18.8 years for females.

$42 \%$ of participants are tobacco users, and $9 \%$ are former tobacco users. Of those with finished secondary school, $48.8 \%$ of them are tobacco users $(\mathrm{N}=21)$, and $43.8 \%$ of those with bachelor's or master's degree $(\mathrm{N}=21)$. There is no statistically significant difference in the number of tobacco users between the two groups concerning their level of education ( $p>0.05)$.

The distribution of the responses to the HU-DBI questionnaire is shown in Table 1. Statistically significant difference was found in the following questions: I brush each of my teeth carefully (Chi-square 4.990, $p=0.026$ ), I put off going to the dentist until I have a toothache (Chi-square 7.056, $p$ $=0.008$ ) and I have had my dentist tell me that I brush very well. (Chi-square 5.841, $\mathrm{p}=0.016$ ).

When calculating the HU-DBI score, one point is assigned to each "agree" answer on " $A$ " questions and one point for each "disagree" answer on " $D$ " questions. The possible maximum HU-DBI score is 12 .

The mean total HU-DBI score was 5.4898 in the first group SSN, and 6.2549 in the second group BSN/MSN.

The difference in total HU-DBI scores between the two groups was statistically significant (Mann-Whitney test $=944.500, p=0.033)$; nurses with a finished secondary school have a significantly lower HU-DBI score in comparison to nurses with a bachelor's or master's degree.

\section{Discussion}

The HU-DBI questionnaire is frequently used in studies aiming to assess knowledge, attitudes and habits regarding oral health.

Besides the study by Kawamura et al. with general nursing students, there are no cross-sectional studies (that use HU$\mathrm{DBI}$ ) on this profile of health personnel to compare our study with. The study by Kawamura concluded that knowledge, attitudes and habits regarding oral health appeared to reflect the differences in schooling [4].

Other studies, by Lujo et al. [6], Yildiz et al. [8], Badovinac et al. [2], Pacauiskene et al. [9], and Al-Wahadini et al. [10], showed significant differences in total HU-DBI score and in results of item 9 (I brush each of my teeth carefully.) concerning educational level, just like results of this study did. But these studies were conducted on dental medicine students, dental technology students, and dental hygiene students $[2,6,8,9,10]$.

The mean total HU-DBI score of nurses working in Clinical Hospital Center Rijeka was 5.88 (5.59 for SSN, 6.25 for BSN/ MSN), which is below recorded total scores (6.65) for second-year general nursing students and the same as first year's total score (5.88) in the study by Kawamura et al. [4]. 
TABLE [1] Distribution of answers to HU-DBI questionnaire items by nurses with finished secondary school and nurses with bachelor's or master's degree

\begin{tabular}{|c|c|c|c|c|c|}
\hline Question & & $\begin{array}{l}\text { SSN } \\
\text { n (\%) }\end{array}$ & $\begin{array}{c}\text { BSN / MSN } \\
n(\%)\end{array}$ & $\begin{array}{l}\text { total } \\
\text { n (\%) }\end{array}$ & p-value \\
\hline \multirow[t]{2}{*}{ 1. I don't worry much about visiting the dentist. } & A & $10(20.4 \%)$ & $8(15.7 \%)$ & $18(18.0 \%)$ & \multirow[t]{2}{*}{0.541} \\
\hline & $\mathrm{D}$ & $39(79.6 \%)$ & $43(84.3 \%)$ & $82(82.0 \%)$ & \\
\hline \multirow[t]{2}{*}{ 2. My gums tend to bleed when I brush my teeth. D } & A & $14(28.65)$ & $10(20.0 \%)$ & $24(24.2 \%)$ & \multirow[t]{2}{*}{0.322} \\
\hline & $\mathrm{D}$ & 35 (71.4\%) & $40(80.0 \%)$ & $75(75.8 \%)$ & \\
\hline \multirow[t]{2}{*}{ 3. I worry about the color of my teeth. } & A & $16(32.7 \%)$ & $23(45.1 \%)$ & $39(39.0 \%)$ & \multirow[t]{2}{*}{0.204} \\
\hline & $\mathrm{D}$ & $33(67.3 \%)$ & $28(54.9 \%)$ & $61(61.0 \%)$ & \\
\hline \multirow{2}{*}{$\begin{array}{l}\text { 4. I have noticed some white sticky deposits on my } \\
\text { teeth. A }\end{array}$} & A & $4(8.2 \%)$ & $2(3.9 \%)$ & $6(6.0 \%)$ & \multirow[t]{2}{*}{0.374} \\
\hline & $\mathrm{D}$ & $45(91.8 \%)$ & $49(96.1 \%)$ & $94(94.0 \%)$ & \\
\hline \multirow[t]{2}{*}{ 5. I use a child sized toothbrush. } & A & $2(4.1 \%)$ & $5(9.8 \%)$ & $7(7.0 \%)$ & \multirow[t]{2}{*}{0.265} \\
\hline & $\mathrm{D}$ & $47(95.9 \%)$ & $46(90.2 \%)$ & $93(93.0 \%)$ & \\
\hline \multirow{2}{*}{$\begin{array}{l}\text { 6. I think that I cannot help having false teeth when I am } \\
\text { old. D }\end{array}$} & A & $21(42.9 \%)$ & $19(37.3 \%)$ & $40(40.0 \%)$ & \multirow[t]{2}{*}{0.569} \\
\hline & $\mathrm{D}$ & $28(57.1 \%)$ & $32(62.7 \%)$ & $60(60.0 \%)$ & \\
\hline \multirow[t]{2}{*}{ 7. I am bothered by the color of my gums. } & A & $12(24.5 \%)$ & $6(11.8 \%)$ & $18(18.0 \%)$ & \multirow[t]{2}{*}{0.099} \\
\hline & $\mathrm{D}$ & $37(75.5 \%)$ & $45(88.2 \%)$ & $82(82.0 \%)$ & \\
\hline \multirow{2}{*}{$\begin{array}{l}\text { 8. I think my teeth are getting worse despite my daily } \\
\text { brushing. D }\end{array}$} & A & $12(24.5 \%)$ & $11(21.6 \%)$ & $23(23.0 \%)$ & \multirow[t]{2}{*}{0.730} \\
\hline & $\mathrm{D}$ & $37(75.5 \%)$ & 40 (78.4\%) & $77(77.0 \%)$ & \\
\hline \multirow[t]{2}{*}{ 9. I brush each of my teeth carefully. A } & A & $26(53.1 \%)$ & $38(74.5 \%)$ & $64(64.0 \%)$ & \multirow[t]{2}{*}{0.026} \\
\hline & $\mathrm{D}$ & $23(46.9 \%)$ & $13(25.5 \%)$ & $36(36.0 \%)$ & \\
\hline \multirow{2}{*}{$\begin{array}{l}\text { 10. I have never been taught professionally how to } \\
\text { brush. D }\end{array}$} & A & $19(38.8 \%)$ & $21(41.2 \%)$ & $40(40.0 \%)$ & \multirow[t]{2}{*}{0.807} \\
\hline & $\mathrm{D}$ & $30(61.2 \%)$ & $30(58.8 \%)$ & $60(60.0 \%)$ & \\
\hline \multirow{2}{*}{$\begin{array}{l}\text { 11. I think I can clean my teeth well without using tooth } \\
\text { paste. A }\end{array}$} & A & $4(8.2 \%)$ & $10(19.6 \%)$ & $14(14.0 \%)$ & \multirow[t]{2}{*}{0.101} \\
\hline & $\mathrm{D}$ & $45(91.8 \%)$ & $41(80.4 \%)$ & $86(86.0 \%)$ & \\
\hline \multirow[t]{2}{*}{ 12. I often check my teeth in a mirror after brushing. $A$} & A & $36(73.5 \%)$ & $43(84.3 \%)$ & $79(79.0 \%)$ & \multirow[t]{2}{*}{0.185} \\
\hline & $\mathrm{D}$ & $13(26.5 \%)$ & $8(15.7 \%)$ & $21(21.0 \%)$ & \\
\hline \multirow[t]{2}{*}{ 13. I worry about having a bad breath. } & A & $21(42.9 \%)$ & $17(33.3 \%)$ & $38(38.0 \%)$ & \multirow[t]{2}{*}{0.329} \\
\hline & $\mathrm{D}$ & $28(57.1 \%)$ & $34(66.7 \%)$ & $62(62.0 \%)$ & \\
\hline 14. It is impossible to prevent gum disease with tooth & A & $29(59.2 \%)$ & $30(58.8 \%)$ & $59(59,0 \%)$ & 0.971 \\
\hline brushir & $\mathrm{D}$ & $20(40.8 \%)$ & $21(41.2 \%)$ & $41(41.0 \%)$ & \\
\hline 15. I put off going to the dentist until I have a toothache. & A & $18(36.7 \%)$ & $7(13.7 \%)$ & $25(25.0 \%)$ & 0.008 \\
\hline D & $\mathrm{D}$ & $31(63.3 \%)$ & $44(86.3 \%)$ & $75(25.0 \%)$ & \\
\hline 16. I have used a dye to see how clean my teeth are. A & A & $8(16.3 \%)$ & $10(19.6 \%)$ & $18(18.0 \%)$ & 0.671 \\
\hline & $\mathrm{D}$ & $41(83.7 \%)$ & $41(80.4 \%)$ & $82(82.0 \%)$ & \\
\hline 17. I use a toothbrush which has hard bristles. & A & $17(34.7 \%)$ & $15(29.4 \%)$ & $32(32.0 \%)$ & 0.573 \\
\hline & $\mathrm{D}$ & $32(65.3 \%)$ & $36(70.6 \%)$ & $68(68.0 \%)$ & \\
\hline 18. I don't feel I've brushed well unless I brush with & A & $16(32.7 \%)$ & $15(29.4 \%)$ & $31(31.0 \%)$ & 0.727 \\
\hline strc & $\mathrm{D}$ & $33(67.3 \%)$ & $36(70.6 \%)$ & $69(69.0 \%)$ & \\
\hline 19. I feel I sometimes take too much time to brush my & A & $10(20.4 \%)$ & $9(17.6 \%)$ & $19(19.0 \%)$ & 0.726 \\
\hline tee & $\mathrm{D}$ & $39(79.6 \%)$ & $42(82.4 \%)$ & $81(81.0 \%)$ & \\
\hline 20. I have had my dentist tell me that I brush very well. & A & $17(34.7 \%)$ & $30(58.8 \%)$ & $47(47.0 \%)$ & 0.016 \\
\hline & $\mathrm{D}$ & $32(65.3 \%)$ & $21(41.2 \%)$ & $53(53.0 \%)$ & \\
\hline
\end{tabular}

SSN - completed secondary school for nurses

BSN - bachelor's degree in nursing, MSN - master's degree in nursing

A - agree, D - disagree 
Also, the total score was lower than the total scores (8.06, $6.45,6.62$ ) among dental students in Croatia $[2,6]$.

Studies that used other questionnaires, not the HU-DBI, also demonstrated a lack of self-reported oral health knowledge among nurses [11-13]. One of these studies showed poor knowledge about preventive dentistry in primary care nursing. It also showed better knowledge among female nurses and better knowledge among public health nurses in respect to other categories [12]. One that was conducted on critical care nurses found that their oral health knowledge is inadequate which makes them unprepared for caring for the oral health of critically ill patients [11].

This research showed significant differences in correlation with educational level - nurses with higher education take better care of their oral health, they also showed better knowledge of existing means and procedures used in oral hygiene, and they have better attitudes towards dental visits and treatments. It is anticipated that they will apply their knowledge in their daily work with patients and finally, with a good education of nurses patients' health improves.

Why do we emphasize nurses' education on oral health and inpatients' health? Researches showed a worsening of oral health measures and deterioration of oral health in hospitalized patients [14-19]. Not only that poor oral health affects oral functions (enabling them to taste, eat and speak) and psychological wellbeing but it represents the risk for local or systemic spread of oral microorganisms [14-19]. Dental plaque microorganisms may be the specific source of nosocomial infection in intensive care unit patients [18]. Also, a significant correlation exists between oral hygiene level (dental plaque index and tongue plaque index) according to the number of febrile days and pneumonia [20]. Furthermore, good oral hygiene is associated with a decrease in developing ventilator-associated pneumonia in hospitalized patients [21]. Other than pulmonary diseases, oral health is associated with cardiovascular disease, dementia, and diabetes mellitus [22-25].

Lastly, tobacco use is an inappropriate habit. Tobacco smoke firstly and directly comes in the oral cavity, where it: affects saliva composition, increases the risk for periodontal disease, negatively affects dental procedures, and consequently leads even to tooth loss [26-28]. Despite all these negative effects of tobacco smoke on oral health, almost one-half of the participants are tobacco users.

To conclude, this research showed that nurses with higher education (bachelor's or master's degrees in nursing) have more knowledge and better attitudes and habits regarding oral health than nurses with finished high school and we expect that they apply this knowledge and attitudes in their everyday practices.

Evidently, sufficient formal education (introducing new subjects or improving existing) on basic preventive dentistry should be provided to nursing students starting from secondary school.

To have more accurate results, it is needed to include more nurses, not only from Clinical Hospital Center Rijeka but also from other hospitals in Croatia.

\section{Ethical standards}

The study was in accordance with the ethical standards of the institution and with the Helsinki Declaration.

\section{Nema sukoba interesa}

Authors declare no conflict of interest

\section{References}

[1] Glažar I. Priručnik oralne higijene. $1^{\text {st }}$ Edition. Rijeka: Medicinski fakultet Sveučilišta u Rijeci, 2017.

[2] Badovinac A, Božić D, Vučinac I, Vešligaj J, Vražić D, Plancak D. Oral health attitudes and behavior of dental students at the University of Zagreb, Croatia. J Dent Educ. 2013; 77 (9): 1171-8.

[3] Azodo CC, Ezeja EB, Ehizele AO, Ehigiator O. Oral assessment and nursing interventions among nigerian nurses-knowledge, practices and educational needs. Ethiop J Health Sci. 2013; 23 (3): 265-70.

[4] Kawamura M, Ikeda-Nakaoka Y, Sasahara H. An assessment of oral self-care level among Japanese dental hygiene students and general nursing students using the Hiroshima University-Dental Behavioural Inventory (HU-DBI): Surveyes in 1990/1999. Eur J Dent Educ. 2000; 4: 82-8.

[5] Jimenez-Baez MV, Acuna-Reyes R, Cigarroa-Martinez D, Urena-Bogarin $E$, Orgaz-Fernandez JD. Practice of preventive dentistry for nursing staff in primary care. Colomb Med (Cali). 2014; 30; 45(3):117-21.

[6] Lujo M, Meštrović M,Ivanišević Malčić A, Karlović Z, Matijević J, Jukić $S$. Knowledge, attitudes and habits regarding oral health in first-and final-year dental students. Acta Clin Croat. 2016; 55: 636-43.

[7] Kawamura M, Sasahara H, Kawabata K, Iwamoto Y, Konishi K, Wright FA. Relationship between CPITN and oral health behaviour in Japanese adults. Aust Dent J. 1993; 38 (5): 381-8.

[8] Yildiz S, Dogan B. Self reported dental health attitudes and behaviour of dental students in Turkey. Eur J Dent. 2011; 5 (3): 253-9.

[9] Pacauskiene IM, Smailiene D, Siudikiene J, Savanevskyte J, Nedzelskiene I. Self-reported oral health behaviour and attitudes of dental and technology students in Lithuania. Stomatologija. 2014; 16 (2): 65-71.

[10] Al-Wahadini AM, Al-Omiri MK, Kawamura M. Differences in self-reported oral health behavior between dental students and dental technology/dental hygiene students in Jordan. J Oral Sci. 2004; 46 (3): 191-7.

[11] Chan EY, Hui-Ling Ng I. Oral care practices among critical care nurses in Singapore: a questionnaire survey. Appl Nurs Res. 2012; 25 (3): 197-204.

[12] Jiménez-Báez MV, Acuña-Reyes R, Cigarroa-Martínez D, Ureña-Bogarín E, Orgaz-Fernández JD. Practice of preventive dentistry for nursing staff in primary care. Colomb Med (Cali). 2014; 45 (3): 117-21.

[13] Mattheus D, Shannon M, Gandhi K, Lim E. Oral Health Knowledge and Practices of Pediatric and Family Nurse Practitioners. J Pediatr Health Care. 2018; 32 (4): 356-62.

[14] Michaeli L, Davis DM, Foxton R. Denture loss: an 8-month study in a community dental setting. Gerodontology. 2007; 24 (2): 117-20.

[15] Adams R. Qualified nurses lack adequate knowledge related to oral health, resulting in inadequate oral care of patients on medical wards. J Adv Nurs. 1996; 24 (3): 552-60.

[16] Peltola P, Vehkalahti MM, Wuolijoki-Saaristo K. Oral health and treatment needs of the long-term hospitalised elderly. Gerodontology. 2004; 21 (2): 93-9.

[17] Franklin D, Senior N, James I, Roberts G. Oral health status of children in a Paediatric Intensive Care Unit. Intensive Care Med. 2000; 26 (3): 319-24.

[18] Fourrier F, Duvivier B, Boutigny H, Roussel-Delvallez M, Chopin C. Colonization of dental plaque: a source of nosocomial infections in intensive care unit patients. Crit Care Med. 1998; 26 (2): 301-8.

[19] Sousa LL, Silva Filho WL, Mendes RF, Moita Neto JM, Prado Junior RR. Oral health of patients under short hospitalization period: observational study. J Clin Periodontol. 2014; 41 (6): 558-63.

[20] Abe S, Ishihara K, Adachi M, Okuda K. Oral hygiene evaluation for effective oral care in preventing pneumonia in dentate elderly. Arch Gerontol Geriatr. 2006; 43 (1): 53-64. 
[21] Shi Z, Xie H, Wang P, et al. Oral hygiene care for critically ill patients to prevent ventilator-associated pneumonia. Cochrane Database Syst Rev. 2013; (8): CD008367.

[22] Manger D, Walshaw M, Fitzgerald R, et al. Evidence summary: the relationship between oral health and pulmonary disease. Br Dent J. 2017;222(7):527-33.

[23] Dietrich T, Webb I, Stenhouse L, et al. Evidence summary: the relationship between oral and cardiovascular disease. Br Dent J. 2017; 222 (5): $381-5$.

[24] Daly B, Thompsell A, Sharpling J, et al. Evidence summary: the relationship between oral health and dementia. Br Dent J. 2018; 223 (11): 846-53.
[25] D'Aiuto F, Gable D, Syed Z, et al. Evidence summary: The relationship between oral diseases and diabetes. Br Dent J. 2017; 222 (12): 944-8.

[26] Arbabi-Kalati F, Salimi S, Nabavi S, Rigi S, Miri-Moghaddam M. Effects of Tobacco on Salivary Antioxidative and Immunologic Systems. Asian Pac J Cancer Prev. 20171; 18 (5): 1215-8.

[27] Ramôa CP, Eissenberg T, Sahingur SE. Increasing popularity of waterpipe tobacco smoking and electronic cigarette use: Implications for oral healthcare. J Periodontal Res. 2017; 52 (5): 813-23.

[28] Cunningham TJ, Eke PI, Ford ES, Agaku IT, Wheaton AG, Croft JB. Cigarette Smoking, Tooth Loss, and Chronic Obstructive Pulmonary Disease: Findings From the Behavioral Risk Factor Surveillance System. J Periodontol. 2016 ; 87 (4): 385-94. 